\title{
Uphill Running Excessive Training Increases Gastrocnemius Glycogen Content in C57BL/6 Mice
}

\author{
G. P. MORAIS ${ }^{1}$, A. DA ROCHA ${ }^{2}$, A. P. PINTO ${ }^{2}$, L. DA C. OLIVEIRA ${ }^{2}$, \\ L. G. DE VICENTE ${ }^{2}$, G. N. FERREIRA ${ }^{1}$, E. C. DE FREITAS ${ }^{1}$, A. S. R. DA SILVA ${ }^{1,2}$ \\ ${ }^{1}$ Postgraduate Program in Physical Education and Sport, School of Physical Education and Sport of \\ Ribeirão Preto, University of São Paulo, Ribeirão Preto, Brazil, ${ }^{2}$ Postgraduate Program in \\ Rehabilitation and Functional Performance, Ribeirão Preto Medical School, University of São \\ Paulo, Ribeirão Preto, Brazil
}

Received February 9, 2017

Accepted April 18, 2017

On-line November 10, 2017

\section{Summary}

The main aim of the present investigation was to verify the effects of three overtraining (OT) protocols performed in downhill (OTR/down), uphill (OTR/up) and without inclination (OTR) on the protein levels of Akt (Ser473), AMPKa (Thr172), PGC-1a, plasma membrane GLUT- 1 and GLUT-4 as well as on the glycogen contents in mice gastrocnemius. A trained (TR) protocol was used as positive control. Rodents were divided into naïve $(\mathrm{N}$, sedentary mice), control (CT, sedentary mice submitted to the performance evaluations), TR, OTR/down, OTR/up and OTR groups. At the end of the experimental protocols, gastrocnemius samples were removed and used for immunoblotting analysis as well as for glycogen measurements. There was no significant difference between the experimental groups for the protein levels of pAkt (Ser473), pAMPKa (Thr172), PGC-1a, plasma membrane GLUT-1 and GLUT-4. However, the OTR/up protocol exhibited higher contents of glycogen compared to the CT and TR groups. In summary, the OTR/up group increased the gastrocnemius glycogen content without significant changes of pAkt (Ser473), pAMPKa (Thr172), PGC-1a, plasma membrane GLUT-1 and GLUT-4.

\section{Key words}

Akt • AMPKa • Glycogen • Nonfunctional overreaching • PGC-1a

\section{Corresponding author}

A. S. R. da Silva, Avenida Bandeirantes, 3900, Monte Alegre, 14040-900, Ribeirão Preto, São Paulo, Brasil. Fax: +55-1633150551. E-mail: adelinosanchez@usp.br

\section{Introduction}

The process of training intensification is named overtraining (OT) and may induce the nonfunctional overreaching state (NFOR), which is defined as a performance drop accompanied or not by psychological and hormonal alterations (Meeusen et al. 2013). The carbohydrate hypothesis considers that during long periods of exercise, athletes present a transitory state of hypoglycemia, which can be explained by both the depletion of hepatic and muscular glycogen stores as well as the deficiency of glycolytic metabolic flux in energy generation. After several long-term training sessions, this depletion of glycogen stores may become a chronic problem, especially when there is a deficiency in the intake of this nutrient (Costill et al. 1988). To elucidate the molecular mechanisms linked to NFOR etiology, Pereira et al. (2015c) proposed three OT protocols for mice based on chronic running sessions in downhill (OTR/down), uphill (OTR/up) and without inclination (OTR) that increased the gastrocnemius and serum contents of interleukin 6 (IL-6) (Pereira et al. 2015a).

Weigert et al. (2005) verified that IL-6 increases insulin-stimulated glycogen synthesis and phosphorylation of protein kinase $\mathrm{B}(\mathrm{Akt})$ at serine473. Also, exercise-induced AMP-activated protein kinase (AMPK) activation enhances the translocation of the glucose transporter type 4 (GLUT-4) to the cell surface and the 
skeletal muscle glycogen content during recovery (Winder and Hardie 1996, Winder and Hardie 1999). GLUT-1 is another cell membrane transporter that regulates glucose uptake in skeletal muscle cells (Manchester et al. 1996). On the other hand, IL-6 directly activates the AMPK in skeletal muscle both in vivo and in vitro (Kelly et al. 2009, Kelly et al. 2004). Kelly et al. (2009) also observed that incubation of skeletal muscle samples with IL-6 increased the glycogenolysis and the protein levels of one of the AMPK genes that acts on mitochondria, the peroxisome proliferator-activated receptor-gamma coactivator $1 \alpha$ (PGC- $1 \alpha)$. These authors proposed that IL-6 acts as an autocrine or paracrine factor, enhancing lipolysis and glycogenolysis as well as activating AMPK in the muscle cells during exercise.

Based on these investigations (Kelly et al. 2009, Lukaszuk et al. 2012, Pereira et al. 2015c, Weigert et al. 2005, Winder and Hardie 1996, Winder and Hardie 1999), we verified the effects of the OTR/down, OTR/up and OTR protocols on the protein levels of Akt, AMPK $\alpha$, PGC-1 $\alpha$, plasma membrane GLUT-1 and GLUT-4 as well as on the glycogen contents in mice gastrocnemius. We hypothesize that the OT protocols-induced performance decline is not linked to low levels of muscle glycogen. In fact, we consider that the overtrained rodents will present activation of Akt and AMPK $\alpha$ with enhancement of the translocation of the GLUT-1 and GLUT-4 to the cell surface. As a positive control, we used a trained (TR) protocol that leads to performance increment (Ferreira et al. 2007, Pereira et al. 2012, Pereira et al. 2013, Pereira et al. 2014a, Pereira et al. 2014b).

\section{Methods}

Eight-week-old male C57BL/6 rodents from the Central Animal Facility of the Ribeirão Preto campus were maintained in individual cages with controlled temperature $\left(22 \pm 2{ }^{\circ} \mathrm{C}\right)$ on a 12:12-h light-dark inverted cycle with food (Purina chow) and water ad libitum. The experimental procedures were approved by the Ethics Committee of the University of Sao Paulo (ID 14.1.873.53.0). Mice were randomly divided into naïve ( $\mathrm{N}$; sedentary mice), control (CT; sedentary mice submitted to the performance evaluations), trained (TR), overtrained by downhill running (OTR/down), overtrained by uphill running (OTR/up) and overtrained by running without inclination (OTR). The $\mathrm{N}$ group was inserted to guarantee that the alterations observed in the CT group did not occur in response to the acute exercise effects (i.e. performance tests).

While the 8-week training protocol was based on the investigation of Ferreira et al. (2007), the 8-week overtraining protocols were performed as previously described (da Rocha et al. 2015, Pereira et al. 2015a, Pereira et al. 2015b). Both training and overtraining protocols consisted of 5 days of continuous training interposed by two days of recovery. The performance evaluations were applied on week 0 and $48 \mathrm{~h}$ after the last sessions of the TR and OT protocols at the end of weeks 4 and 8 and consisted of the rotarod test, the incremental load test, the exhaustive test and the grip force test (Anderson et al. 2004, da Rocha et al. 2015, da Rocha et al. 2016a, Pereira et al. 2015a, Pereira et al. 2015b, Turgeman et al. 2008). The detailed description of these performance evaluations and the effects of the TR and OT protocols have been previously published in other studies by our research group (da Rocha et al. 2015, da Rocha et al. 2016a, Pereira et al. 2015a, Pereira et al. 2012, Pereira et al. 2015b, Pereira et al. 2013, Pereira et al. 2014a, Pereira et al. 2014b).

Thirty-six hours after the grip force test performed at the end of the TR and OT protocols, the fasted rodents (i.e. $12 \mathrm{~h}$ ) were anesthetized with an intraperitoneal (i.p.) injection of $2.5 \%\left(10-20 \mu \mathrm{l}^{-1} \mathrm{~g}^{-1}\right)$ 2,2,2-tribromoethanol. As soon as anesthesia was confirmed by the loss of the pedal reflexes, the abdominal cavity was opened, the portal vein was exposed, and saline with and without human recombinant insulin (10 U.kg-1 ${ }^{-1}$ Eli Lilly, Indianapolis, IN) was injected. At $90 \mathrm{~s}$ after saline or saline with human recombinant insulin injection (Pauli et al. 2008, Ropelle et al. 2006), gastrocnemius samples were removed and used for immunoblotting analysis as previously described (da Rocha et al. 2015, da Rocha et al. 2016a, da Rocha et al. 2017, Pereira et al. 2015a, Pereira et al. 2012, Pereira et al. 2015b, Pereira et al. 2014a, Pereira et al. 2014b). Herein, we used the following antibodies: beta-actin (SC69879), GLUT-4 (SC53566) and PGC-1 $\alpha$ (SC13067) from Santa Cruz Biotechnology (Santa Cruz, CA, USA) at dilution of 1:750; Akt (CELL9272S), phospho-Akt (Ser473; CELL4058S), AMPK $\alpha$ (CELL2532S), phospho(p)-AMPKa (Thr172; CELL2535S) and GLUT-1 (CELL12939S) from Cell Signaling Technology (Beverly, MA, USA) at dilution of 1:1,000.

The plasma membrane fractions were obtained 
as previously described (Gasparetti et al. 2003, Mizukami et al. 1997, Pereira et al. 2016) and aliquots were subjected to the immunoblotting analysis with the following antibodies: GLUT-4 (SC53566) and GLUT-1 (CELL12939S) for plasma membrane aliquots. The gastrocnemius glycogen contents were measured as described by Dubois et al. (1951). Results are expressed as the mean \pm standard error of the mean (SE). A one-way ANOVA was used to examine the responses of the analyzed parameters to the experimental groups. When one-way ANOVA indicated statistical significance, a Bonferroni's post hoc test was performed. All statistical analyses were two-sided, and the significance level was set at $\mathrm{P}<0.05$.

\section{Results}

There was no significant difference between the experimental groups for the protein levels of $\mathrm{pAkt}$ (Ser473; Fig. 1A), pAMPK $\alpha$ (Thr172; Fig. 1B), PGC-1 $\alpha$ (Fig. 1C), plasma membrane GLUT-1 (Fig. 1D) and GLUT-4 (Fig. 1E). On the other hand, Figure 1F shows that the gastrocnemius glycogen content was significantly higher for the OTR/up group $(0.28 \pm 0.04 \mathrm{mg} / \mathrm{g})$ compared to the CT $(0.15 \pm 0.01 \mathrm{mg} / \mathrm{g})$ and TR $(0.12 \pm 0.02 \mathrm{mg} / \mathrm{g})$ groups. The effect sizes of pAkt (with insulin stimulation), pAkt (without insulin stimulation), pAMPK $\alpha$, PGC-1 $\alpha$, plasma membrane GLUT-1, GLUT-4 and gastrocnemius glycogen are 0.84, 0.74, $0.42,0.25,0.49,0.42$ and 0.92 , respectively.

\section{Discussion}

Recently, we verified that the pAkt (Ser473) was lower in the extensor digitorum longus (EDL) and soleus after the OTR/down and in the soleus after the OTR/up and OTR (Pereira et al. 2016). Also, the pAkt (Ser473) was higher after the OTR/up in the EDL. Herein, this protein was not changed after the experimental protocols. These data show that each skeletal muscle presents a different adaptation in response to the same OT protocols. Weigert et al. (2005) showed that IL-6 enhances pAkt (Ser473) in mouse muscle; however, they used $50 \mathrm{ng}$ of mouse recombinant IL-6 that was injected intraperitoneally. Our overtrained rodents displayed increased levels of IL- 6 in both gastrocnemius and serum samples (Pereira et al. 2015a), which were not sufficient to increase the gastrocnemius contents of pAkt (Ser473).
To our knowledge, this is the first study showing the effects of different OT models on the protein levels of pAMPK $\alpha$ (Thr172) and PGC-1 $\alpha$ in skeletal muscle samples. Although not significant, the protein levels of pAMPK $\alpha$ (Thr172) for the OTR/up were approximately 84 and $137 \%$ higher compared to the N and TR. Also, the training intensity of the OTR/up was $43.8 \%$ higher compared to the TR. Both AMPK activity and its phosphorylation at threonine 172 are dependent on exercise intensity in humans and rodents (Chen et al. 2003, Egan et al. 2010, Rasmussen and Winder 1997, Schwalm et al. 2015, Tadaishi et al. 2011, Wadley et al. 2006, Wojtaszewski et al. 2000). The relative intensities of the OTR/down and OTR were the same as in the OTR/up; however, the energy cost and mitochondrial adaptation are higher in uphill compared to downhill and running without inclination (Chavanelle et al. 2014, Cornachione et al. 2011, Schlagowski et al. 2016, Vernillo et al. 2017).

An important factor that may have influenced the lack of significant alterations in the protein contents of pAMPK $\alpha$ (Thr172) after the TR and OT protocols is the extraction time of the gastrocnemius samples. Regarding the effects of acute and chronic exercise models on the time-course of the intramuscular activation of pAMPKa (Thr172) in humans and rodents, the investigations described a range of significant responses between immediately post-exercise and $6 \mathrm{~h}$ of recovery (Camera et al. 2010, Gehlert et al. 2012, Halling et al. 2016, Huh et al. 2014, Sriwijitkamol et al. 2007). Recently, Wang et al. (2016) verified that nine swimming bouts (i.e. $10 \mathrm{~min} /$ bout) with 10 -min rest periods between each bout did not change pAMPK $\alpha$ (Thr172) levels in rat soleus muscles that were or not stimulated with insulin. In accordance, after six weeks of progressively increasing intensity stationary cycle cycling, Stuart et al. (2010) did not observe significant responses of pAMPK $\alpha$ (Thr172) contents in human vastus lateralis muscle biopsies. The extraction times of the skeletal muscle samples previously described were from 3 to $4 \mathrm{~h}$ (Wang et al. 2016) and $48 \mathrm{~h}$ (Stuart et al. 2010) after the conclusion of the exercise sessions.

In an elegant investigation, Jager et al. (2007) showed that AMPK needs PGC- $1 \alpha$ for many of its most relevant effects on GLUT-4 translocation in skeletal muscles. Also, Leick et al. (2010) suggested that PGC-1 $\alpha$ mediates AMPK-induced GLUT-4 regulation in response to chronic exercise. They also verified that the 
A

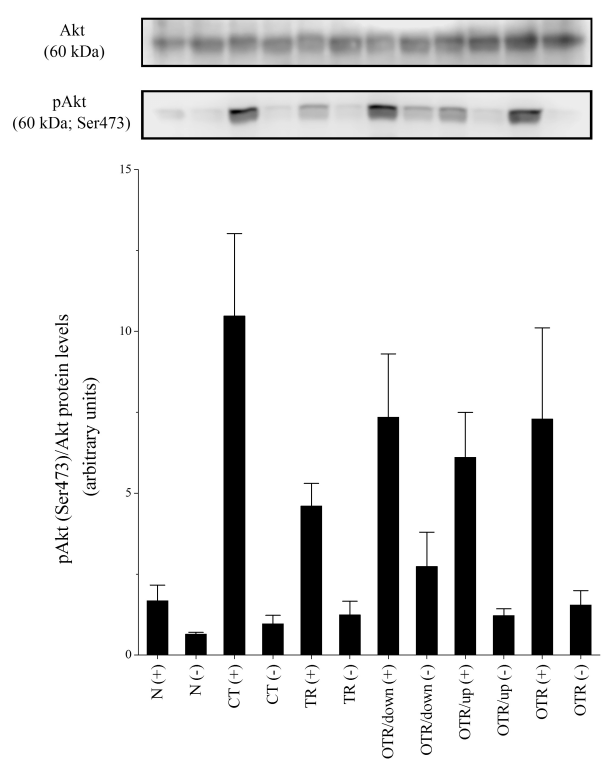

$\mathrm{C}$
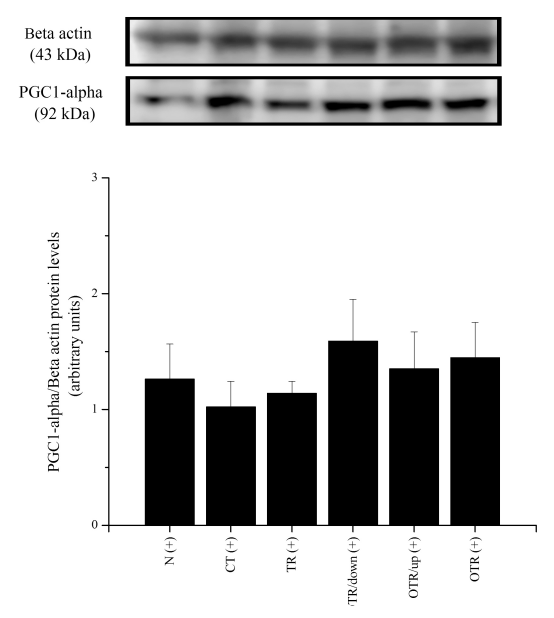

$\mathrm{E}$
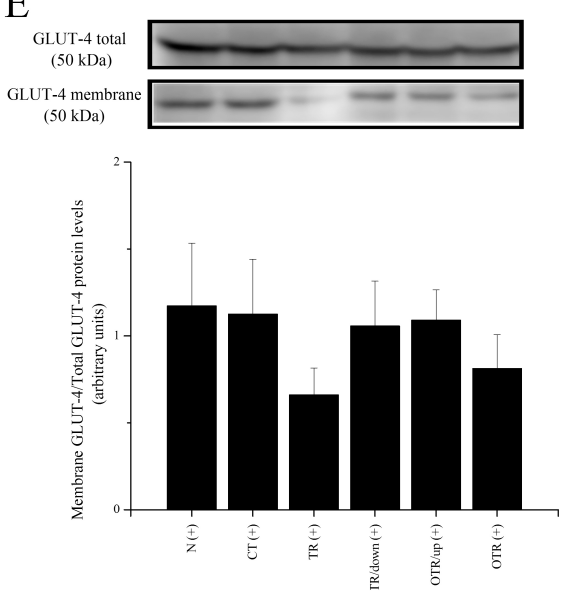

B

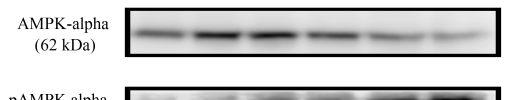

(62 kDa; Thr172) ए -

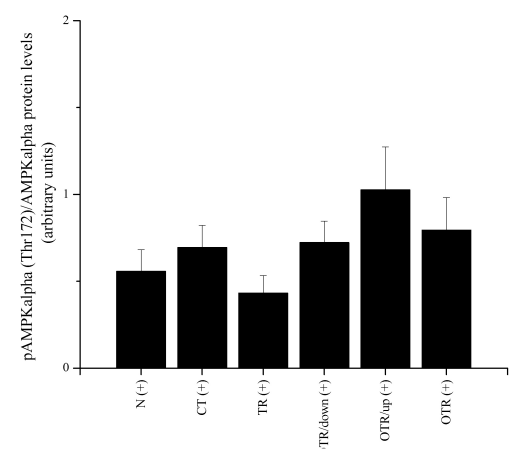

$\mathrm{D}$
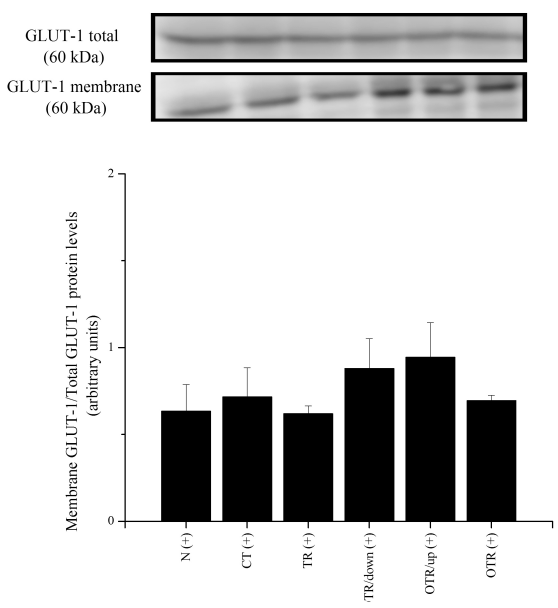

F

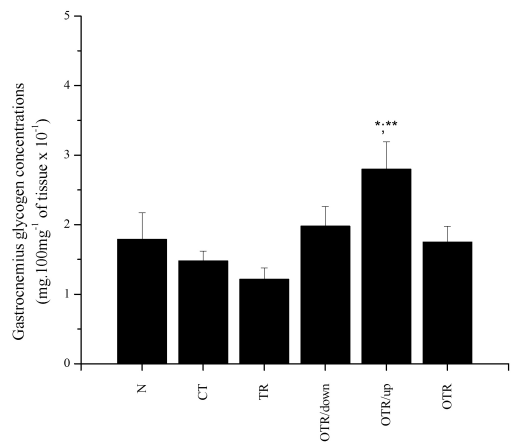

Fig. 1. Protein levels (arbitrary units) of pAkt (Ser473)/Akt (A), pAMPKa (Thr172)/AMPKa (B), PGC-1a/beta-actin (C), membrane GLUT-1/total GLUT-1 (D), membrane GLUT-4/total GLUT-4 (E) and glycogen concentrations (F); mg.100 mg ${ }^{-1}$ of tissue $\times 10^{-1}$ ) in gastrocnemius for the experimental groups. The original experiments correspond to means $\pm S E$ of $n=8$ mice [i.e. $n=8$ gastrocnemius with insulin stimulation $(+)$ and $n=8$ gastrocnemius without insulin stimulation (-)]. N: sedentary mice; TR: trained mice; CT: sedentary mice; OTR/down: overtrained by downhill running; OTR/up: overtrained by uphill running; OTR: overtrained by running without inclination. ${ }^{*} \mathrm{P}<0.05$ vs. the $\mathrm{CT}$ group; ${ }^{* *} \mathrm{P}<0.05$ vs. the TR group. The original experiments of Figures $1 \mathrm{~A}-1 \mathrm{D}$ are available in the Supplementary Figures 1 and 2 . The blots circled in red were used as representative in the respective Figures. 
absence of PGC-1 $\alpha$ attenuates the skeletal muscle glycogen increase. As the pAMPK $\alpha$ (Thr172) responses, we also did not observe statistical changes of the intramuscular levels of PGC- $1 \alpha$ after the TR and OT models. Because the proteins and their targets are phosphorylated at distinct times (Kholodenko 2006), future investigations should measure the time-course of the gastrocnemius levels of pAMPK $\alpha$ (Thr172) and PGC-1 $\alpha$ after the TR and OT protocols to clarify whether they were activated before or after the current extraction time. Probably, the current extraction time of the gastrocnemius muscle was the main limitation of the study.

Recently, we showed that the OTR/down downregulated the plasma membrane GLUT-4 contents in both EDL and soleus samples, while the OTR/up and OTR downregulated this protein only in soleus sample (Pereira et al. 2016). We argued that the soleus was more recruited than the EDL during the 8 weeks of the OTR/up and OTR. In accordance, Carter et al. (1994) concluded that exhaustive concentric exercise might preferentially impair slow twitch fibers. Our research group also observed that these three OT models improved glucose tolerance even with reduced insulin signaling in EDL and soleus (Pereira et al. 2016). This finding probably occurred because other tissues such as liver did not present inhibition of this pathway, playing a crucial role in glucose homeostasis (Kotani et al. 2004, Zisman et al. 2000). In fact, Rocha and coworkers (da Rocha et al. 2015) verified that the OTR/down and OTR/up increased the phosphorylation and inhibition of glycogen synthase kinase 3 beta (GSK3beta), enhancing the hepatic glycogen depositions.

Herein, the OTR/up increased the gastrocnemius glycogen content compared to the CT and TR. According to Armstrong and Taylor (Armstrong and Taylor 1993), the higher the exercise intensity, the faster the skeletal muscle glycogen loss. As previously stated, the training intensity of the OTR/up was $43.8 \%$ higher than the TR. Also, Goforth et al. (2003) verified that subjects completing a depletion carbohydrate (CHO)-loading protocol achieved higher muscle glycogen concentrations that persisted longer in comparison to those completing the non-depletion CHO-loading protocol. Although GLUT-4 is the predominant glucose transporter isoform expressed in skeletal muscle, and its translocation to the plasma membrane promotes glucose uptake (Klip and
Paquet 1990), Fam et al. (2012) verified that the deletion of the skeletal muscle GLUT-4 did not impair the wholebody glucose disposal on a pure C57BL6/J background strain. These and other investigations (Charron et al. 2005, Fam et al. 2012, Ryder et al. 1999) suggested that unidentified GLUTs would be increased to compensate the GLUT-4 absence.

GLUT-1 is also responsible for glucose uptake in skeletal muscle cells (Manchester et al. 1996). When incubated with the tumor necrosis factor- $\alpha$ (TNF- $\alpha$ ), child myotube cultures up-regulated GLUT-1 expression and glucose transport (Grohmann et al. 2005). Also, cultured L6 skeletal muscle cells incubated in the presence of cytokines (i.e. interferon- $\gamma$ and TNF- $\alpha$ ) and lipopolysaccharide (LPS) for $24 \mathrm{~h}$ markedly increased both basal glucose transport and GLUT-1 transporter protein (Bedard et al. 1997). Although our research group verified high contents of TNF- $\alpha$ in the gastrocnemius samples of the OTR/down and OTR/up (Pereira et al. 2015a), the GLUT-1 contents in this particular skeletal muscle sample were not altered after these OT models.

\section{Conclusions}

The current data testified our initial hypothesis suggesting that other mechanisms, except the decrease of skeletal muscle glycogen stores, participate in the performance drop linked to the NFOR state. In fact, we verified that uphill running excessive training increased gastrocnemius glycogen content, but did not lead to significant alterations of pAkt (Ser473), pAMPK $\alpha$ (Thr172), PGC-1 $\alpha$, plasma membrane GLUT-1 and GLUT-4. Figure 2 summarizes the current findings regarding the relationship between the OT protocols and the carbohydrate theory.

\section{Conflict of Interest}

There is no conflict of interest.

\section{Acknowledgements}

The present work received financial support from the São Paulo Research Foundation (FAPESP; process numbers 2013/20591-3, 2014/25459-9, 2015/08013-0, and 201513275-3) and the National Council for Scientific and Technological Development (CNPq; process number 309339/2016-2). The authors are grateful for the technical support provided by Mr. Bruno Cesar Pereira. 


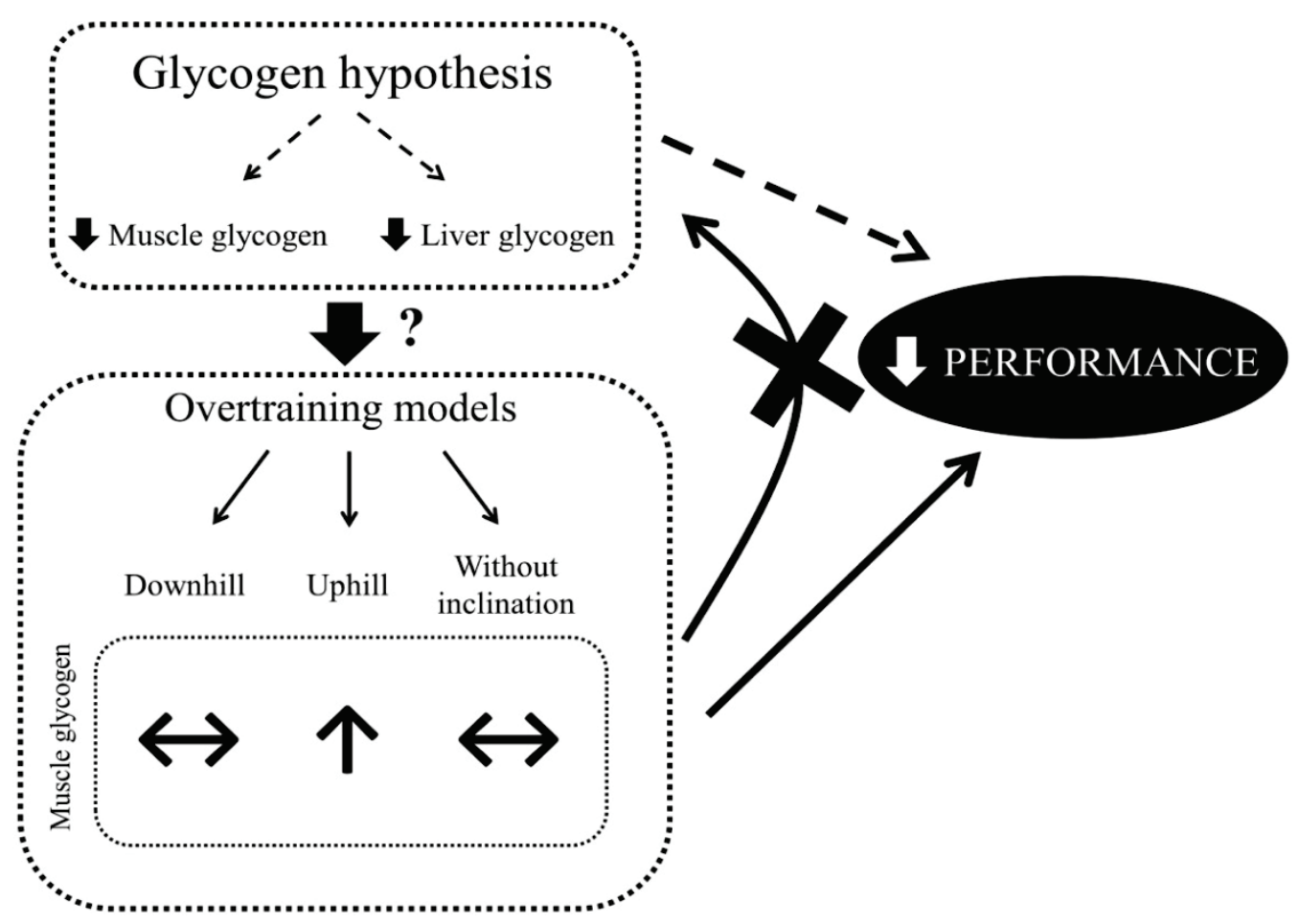

Fig. 2. Schematic model summarizing the current findings regarding the relationship between the OT protocols and the carbohydrate theory.

\section{References}

ANDERSON KD, ABDUL M, STEWARD O: Quantitative assessment of deficits and recovery of forelimb motor function after cervical spinal cord injury in mice. Exp Neurol 190: 184-191, 2004.

ARMSTRONG RB, TAYLOR CR: Glycogen loss in rat muscles during locomotion on different inclines. $J$ Exp Biol 176: 135-144, 1993.

BEDARD S, MARCOTTE B, MARETTE A: Cytokines modulate glucose transport in skeletal muscle by inducing the expression of inducible nitric oxide synthase. Biochem J 325: 487-493, 1997.

CAMERA DM, EDGE J, SHORT MJ, HAWLEY JA, COFFEY VG: Early time course of Akt phosphorylation after endurance and resistance exercise. Med Sci Sports Exerc 42: 1843-1852, 2010.

CARTER GT, KIKUCHI N, ABRESCH RT, WALSH SA, HORASEK SJ, FOWLER WM JR: Effects of exhaustive concentric and eccentric exercise on murine skeletal muscle. Arch Phys Med Rehabil 75: 555-559, 1994.

CHARRON MJ, GOROVITS N, LAIDLAW JS, RANALLETTA M, KATZ EB: Use of GLUT-4 null mice to study skeletal muscle glucose uptake. Clin Exp Pharmacol Physiol 32: 308-313, 2005.

CHAVANELLE V, SIRVENT P, ENNEQUIN G, CAILLAUD K, MONTAURIER C, MORIO B, BOISSEAU N, RICHARD R: Comparison of oxygen consumption in rats during uphill (concentric) and downhill (eccentric) treadmill exercise tests. $J$ Sports Sci Med 13: 689-694, 2014.

CHEN ZP, STEPHENS TJ, MURTHY S, CANNY BJ, HARGREAVES M, WITTERS LA, KEMP BE, MCCONELL GK: Effect of exercise intensity on skeletal muscle AMPK signaling in humans. Diabetes 52: 2205-2212, 2013.

CORNACHIONE A, CAÇÃO-BENEDINI LO, MARTINEZ EZ, NEDER L, CLÁUDIA MATTIELLO-SVERZUT A: Effects of eccentric and concentric training on capillarization and myosin heavy chain contents in rat skeletal muscles after hindlimb suspension. Acta Histochem 113: 277-282, 2011.

COSTILL DL, FLYNN MG, KIRWAN JP, HOUMARD JA, MITCHELL JB, THOMAS R, PARK SH: Effects of repeated days of intensified training on muscle glycogen and swimming performance. Med Sci Sports Exerc 20: $249-254,1988$. 
DA ROCHA AL, PEREIRA BC, PAULI JR, CINTRA DE, DE SOUZA CT, ROPELLE ER, DA SILVA AS: Downhill running-based overtraining protocol improves hepatic insulin signaling pathway without concomitant decrease of inflammatory proteins. PLoS One 10: e0140020, 2015.

DA ROCHA AL, PEREIRA BC, PAULI JR, DE SOUZA CT, TEIXEIRA GR, LIRA FS, CINTRA DE, ROPELLE ER, JUNIOR CR, DA SILVA AS: Downhill running excessive training inhibits hypertrophy in mice skeletal muscles with different fiber type composition. J Cell Physiol 231: 1045-1056, 2016a.

DA ROCHA AL, PINTO AP, TEIXEIRA GR, PEREIRA BC, OLIVEIRA LC, SILVA AC, MORAIS GP, CINTRA DE, PAULI JR, DA SILVA AS: Exhaustive training leads to hepatic fat accumulation. $J$ Cell Physiol 232: 2094-2013, 2017.

DUBOIS M, GILLES K, HAMILTON JK, REBERS PA, SMITH F: A colorimetric method for determination of sugar and related substances. Nature 168: 167, 1951.

EGAN B, CARSON BP, GARCIA-ROVES PM, CHIBALIN AV, SARSFIELD FM, BARRON N, MCCAFFREY N, MOYNA NM, ZIERATH JR, O'GORMAN DJ: Exercise intensity-dependent regulation of peroxisome proliferator-activated receptor coactivator-1 mRNA abundance is associated with differential activation of upstream signalling kinases in human skeletal muscle. J Physiol 588: 1779-1790, 2010.

FAM BC, ROSE LJ, SGAMBELLONE R, RUAN Z, PROIETTO J, ANDRIKOPOULOS S: Normal muscle glucose uptake in mice deficient in muscle GLUT4. J Endocrinol 214: 313-327, 2012.

FERREIRA JC, ROLIM NP, BARTHOLOMEU JB, GOBATTO CA, KOKUBUN E, BRUM PC: Maximal lactate steady state in running mice: effect of exercise training. Clin Exp Pharmacol Physiol 34: 760-765, 2007.

GASPARETTI AL, DE SOUZA CT, PEREIRA-DA-SILVA M, OLIVEIRA RL, SAAD MJ, CARNEIRO EM, VELLOSO LA: Cold exposure induces tissue-specific modulation of the insulin-signalling pathway in Rattus norvegicus. J Physiol 552: 149-162, 2003.

GEHLERT S, BUNGARTZ G, WILLKOMM L, KORKMAZ Y, PFANNKUCHE K, SCHIFFER T, BLOCH W, SUHR F: Intense resistance exercise induces early and transient increases in ryanodine receptor 1 phosphorylation in human skeletal muscle. PLoS One 7: e49326, 2012.

GOFORTH HW JR, LAURENT D, PRUSACZYK WK, SCHNEIDER KE, PETERSEN KF, SHULMAN GI: Effects of depletion exercise and light training on muscle glycogen supercompensation in men. Am J Physiol Endocrinol Metab 285: E1304-E1311, 2003.

GROHMANN M, FOULSTONE E, WELSH G, HOLLY J, SHIELD J, CROWNE E, STEWART C: Isolation and validation of human prepubertal skeletal muscle cells: maturation and metabolic effects of IGF-I, IGFBP-3 and TNFalpha. J Physiol 568: 229-242, 2005.

HALLING JF, RINGHOLM S, NIELSEN MM, OVERBY P, PILEGAARD H: PGC-1alpha promotes exercise-induced autophagy in mouse skeletal muscle. Physiol Rep 4: e12698, 2016.

HUH JY, MOUGIOS V, KABASAKALIS A, FATOUROS I, SIOPI A, DOUROUDOS II, FILIPPAIOS A, PANAGIOTOU G, PARK KH, MANTZOROS CS: Exercise-induced irisin secretion is independent of age or fitness level and increased irisin may directly modulate muscle metabolism through AMPK activation. $J C l i n$ Endocrinol Metab 99: E2154-E2161, 2014.

JAGER S, HANDSCHIN C, PIERRE J, SPIEGELMAN BM: AMP-activated protein kinase (AMPK) action in skeletal muscle via direct phosphorylation of PGC-1 alpha. Proc Natl Acad Sci U S A 104: 12017-12022, 2007.

KELLY M, GAUTHIER MS, SAHA AK, RUDERMAN NB: Activation of AMP-activated protein kinase by interleukin-6 in rat skeletal muscle association with changes in cAMP, energy state, and endogenous fuel mobilization. Diabetes 58: 1953-1960, 2009.

KELLY M, KELLER C, AVILUCEA PR, KELLER P, LUO ZJ, XIANG XQ, GIRALT M, HIDALGO J, SAHA AK, PEDERSEN BK, RUDERMAN NB: AMPK activity is diminished in tissues of IL-6 knockout mice: the effect of exercise. Biochem Biophys Res Commun 320: 449-454, 2004.

KHOLODENKO BN: Cell-signalling dynamics in time and space. Nat Rev Mol Cell Biol 7: 165-176, 2006.

KLIP A, PAQUET MR: Glucose transport and glucose transporters in muscle and their metabolic regulation. Diabetes Care 13: 228-243, 1990.

KOTANI K, PERONI OD, MINOKOSHI Y, BOSS O, KAHN BB: GLUT4 glucose transporter deficiency increases hepatic lipid production and peripheral lipid utilization. J Clin Invest 114: 1666-1675, 2004. 
LEICK L, FENTZ J, BIENSO RS, KNUDSEN JG, JEPPESEN J, KIENS B, WOJTASZEWSKI JF, PILEGAARD H: PGC-1 $\{$ alpha\} is required for AICAR-induced expression of GLUT4 and mitochondrial proteins in mouse skeletal muscle. Am J Physiol Endocrinol Metab 299: E456-E465, 2010.

LUKASZUK B, BIALUK I, GORSKI J, ZAJACZKIEWICZ M, WINNICKA MM, CHABOWSKI A: A single bout of exercise increases the expression of glucose but not fatty acid transporters in skeletal muscle of IL-6 KO mice. Lipids 47: 763-772, 2012.

MANCHESTER J, SKURAT AV, ROACH P, HAUSCHKA SD, LAWRENCE JC JR: Increased glycogen accumulation in transgenic mice overexpressing glycogen synthase in skeletal muscle. Proc Natl Acad Sci U S A 93: 10707-10711, 1996.

MEEUSEN R, DUCLOS M, FOSTER C, FRY A, GLEESON M, NIEMAN D, RAGLIN J, RIETJENS G, STEINACKER J, URHAUSEN A, EUROPEAN COLLEGE OF SPORT SCIENCE, AMERICAN COLLEGE OF SPORTS MEDICINE: Prevention, diagnosis, and treatment of the overtraining syndrome: joint consensus statement of the European College of Sport Science and the American College of Sports Medicine. Med Sci Sports Exerc 45: 186-205, 2013.

MIZUKAMI Y, YOSHIOKA K, MORIMOTO S, YOSHIDA K: A novel mechanism of JNK1 activation. Nuclear translocation and activation of JNK1 during ischemia and reperfusion. J Biol Chem 272: 16657-16662, 1997.

PAULI JR, ROPELLE ER, CINTRA DE, CARVALHO-FILHO MA, MORAES JC, DE SOUZA CT, VELLOSO LA, CARVALHEIRA JB, SAAD MJ: Acute physical exercise reverses S-nitrosation of the insulin receptor, insulin receptor substrate 1 and protein kinase B/Akt in diet-induced obese Wistar rats. $J$ Physiol 586: 659-671, 2008.

PEREIRA BC, FILHO LA, ALVES GF, PAULI JR, ROPELLE ER, SOUZA CT, CINTRA DE, SAAD MJ, SILVA AS: A new overtraining protocol for mice based on downhill running sessions. Clin Exp Pharmacol Physiol 39: 793-798, 2012.

PEREIRA BC, PAUli JR, ANTUNES LM, De FREITAS EC, De ALMEIDA MR, De PAUlA VENANCiO V, ROPELLE ER, DE SOUZA CT, CINTRA DE, PAPOTI M, DA SILVA AS: Overtraining is associated with DNA damage in blood and skeletal muscle cells of Swiss mice. BMC Physiol 13: 11, 2013.

PEREIRA BC, PAULI JR, DE SOUZA CT, ROPELLE ER, CINTRA DE, FREITAS EC, DA SILVA AS: Eccentric exercise leads to performance decrease and insulin signaling impairment. Med Sci Sports Exerc 46: 686-694, 2014a.

PEREIRA BC, PAULI JR, DE SOUZA CT, ROPELLE ER, CINTRA DE, ROCHA EM, FREITAS EC, PAPOTI M, DA SILVA L, LIRA FS, SILVA AS: Nonfunctional overreaching leads to inflammation and myostatin upregulation in Swiss mice. Int J Sports Med 35: 139-146, $2014 \mathrm{~b}$.

PEREIRA BC, DA ROCHA AL, PAULI JR, ROPELlE ER, DE SOUZA CT, CINTRA DE, SANT'ANA MR, DA SILVA AS: Excessive eccentric exercise leads to transitory hypothalamic inflammation, which may contribute to the low body weight gain and food intake in overtrained mice. Neuroscience 311: 231-242, 2015a.

PEREIRA BC, LUCAS G, DA ROCHA AL, PAULI JR, ROPELLE ER, CINTRA D, DE SOUZA CT, BUENO CR, DA SILVA AS: Eccentric exercise leads to glial activation but not apoptosis in mice spinal cords. Int J Sports Med 36: 378-385, 2015 b.

PEREIRA BC, DA ROCHA AL, PINTO AP, PAULI JR, MOURA LP, MEKARY R, DE FREITAS EC, DA SILVA A: Excessive training impairs the insulin signal transduction in mice skeletal muscles. $J$ Endocrinol 230: 93-104, 2016.

RASMUSSEN BB, WINDER WW: Effect of exercise intensity on skeletal muscle malonyl-CoA and acetyl-CoA carboxylase. J Appl Physiol (1985) 83: 1104-1109, 1997.

ROPELLE ER, PAULI JR, PRADA PO, DE SOUZA CT, PICARDI PK, FARIA MC, CINTRA DE, FERNANDES MF, FLORES MB, VELLOSO LA, SAAD MJ, CARVALHEIRA JB: Reversal of diet-induced insulin resistance with a single bout of exercise in the rat: the role of PTP1B and IRS-1 serine phosphorylation. J Physiol 577: 997-1007, 2006.

RYDER JW, KAWANO Y, GALUSKA D, FAHLMAN R, WALLBERG-HENRIKSSON H, CHARRON MJ, ZIERATH JR: Postexercise glucose uptake and glycogen synthesis in skeletal muscle from GLUT4-deficient mice. FASEB J 13: 2246-2256, 1999. 
SCHLAGOWSKI AI, ISNER-HOROBETI ME, DUFOUR SP, RASSENEUR L, ENACHE I, LONSDORFER-WOLF E, DOUTREleau S, CHARlouX A, GOUPILlEAU F, BENTZ I, ET AL.: Mitochondrial function following downhill and/or uphill exercise training in rats. Muscle Nerve 54: 925-935, 2016.

SCHWALM C, JAMART C, BENOIT N, NASLAIN D, PREMONT C, PREVET J, VAN THIENEN R, DELDICQUE L, FRANCAUX M: Activation of autophagy in human skeletal muscle is dependent on exercise intensity and AMPK activation. FASEB J 29: 3515-3526, 2015.

SRIWIJITKAMOL A, COLETTA DK, WAJCBERG E, BALBONTIN GB, REYNA SM, BARRIENTES J, EAGAN PA, JENKINSON CP, CERSOSIMO E, DEFRONZO RA, SAKAMOTO K, MUSI N: Effect of acute exercise on AMPK signaling in skeletal muscle of subjects with type 2 diabetes: a time-course and dose-response study. Diabetes 56: 836-848, 2007.

STUART CA, HOWELL ME, BAKER JD, DYKES RJ, DUFFOURC MM, RAMSEY MW, STONE MH: Cycle training increased GLUT4 and activation of mammalian target of rapamycin in fast twitch muscle fibers. Med Sci Sports Exerc 42: 96-106, 2010.

TADAISHI M, MIURA S, KAI Y, KAWASAKI E, KOSHINAKA K, KAWANAKA K, NAGATA J, OISHI Y, EZAKI O: Effect of exercise intensity and AICAR on isoform-specific expressions of murine skeletal muscle PGC-1alpha mRNA: a role of beta(2)-adrenergic receptor activation. Am J Physiol Endocrinol Metab 300: E341-E349, 2011.

TURGEMAN T, HAGAI Y, HUEBNER K, JASSAL DS, ANDERSON JE, GENIN O, NAGLER A, HALEVY O, PINES M: Prevention of muscle fibrosis and improvement in muscle performance in the $\mathrm{mdx}$ mouse by halofuginone. Neuromuscul Disord 18: 857-868, 2008.

VERNILLO G, GIANDOLINI M, EDWARDS WB, MORIN JB, SAMOZINO P, HORVAIS N, MILLET GY: Biomechanics and physiology of uphill and downhill running. Sports Med 47: 615-629, 2017.

WADLEY GD, LEE-YOUNG RS, CANNY BJ, WASUNTARAWAT C, CHEN ZP, HARGREAVES M, KEMP BE, MCCONELL GK: Effect of exercise intensity and hypoxia on skeletal muscle AMPK signaling and substrate metabolism in humans. Am J Physiol Endocrinol Metab 290: E694-E702, 2006.

WANG H, SHARMA N, ARIAS EB, CARTEE GD: Insulin signaling and glucose uptake in the soleus muscle of 30-month-old rats after calorie restriction with or without acute exercise. J Gerontol A Biol Sci Med Sci 71: 323-332, 2016.

WEIGERT C, HENNIGE AM, BRODBECK K, HARING HU, SCHLEICHER ED: Interleukin-6 acts as insulin sensitizer on glycogen synthesis in human skeletal muscle cells by phosphorylation of Ser(473) of Akt. Am J Physiol Endocrinol Metab 289: E251-E257, 2005.

WINDER WW, HARDIE DG: Inactivation of acetyl-CoA carboxylase and activation of AMP-activated protein kinase in muscle during exercise. Am J Physiol 270: E299-E304, 1996.

WINDER WW, HARDIE DG: AMP-activated protein kinase, a metabolic master switch: possible roles in type 2 diabetes. Am J Physiol 277: E1-E10, 1999.

WOJTASZEWSKI JF, NIELSEN P, HANSEN BF, RICHTER EA, KIENS B: Isoform-specific and exercise intensitydependent activation of 5'-AMP-activated protein kinase in human skeletal muscle. $J$ Physiol 528: 221-226, 2000.

ZISMAN A, PERONI OD, ABEL ED, MICHAEL MD, MAUVAIS-JARVIS F, LOWELL BB, WOJTASZEWSKI JF, HIRSHMAN MF, VIRKAMAKI A, GOODYEAR LJ, KAHN CR, KAHN BB: Targeted disruption of the glucose transporter 4 selectively in muscle causes insulin resistance and glucose intolerance. Nat Med $\mathbf{6}$ : 924-928, 2000. 